\title{
CCND1 Gene
}

National Cancer Institute

\section{Source}

National Cancer Institute. CCND1 Gene. NCI Thesaurus. Code C18021.

This gene plays a role in the regulation of mitotic events. 